\title{
Language Learning Strategies in Speaking Classroom Activity: Extrovert and Introvert Learners
}

\author{
Melia Citra ${ }^{1, *}$ Yetty Zainil $^{1}$ \\ ${ }^{1}$ Universitas Negeri Padang, Padang, Indonesia \\ *Corresponding author.e-mail:meliacitra96@gmail.com
}

\begin{abstract}
The language learning strategy carried out by EFL learners sometimes differ from one another following their personality; however, it is not clearly defined yet. This research aims to analyze students' language learning strategies in a speaking activity in accordance with their personality: extrovert and introvert in the classroom process. The third year of English Department students of Universitas Islam Negeri Imam Bonjol Padang is the subject of this research and 30 students among them were chosen as samples. This research is a descriptive study with a qualitative approach to see natural things which occur to humans and some events or phenomena from the field directly. The data came from the questionnaire, as well as the interview. The questionnaire was used to find out students' personality types, and the interview was conducted with students to investigate what the students think about their learning strategies as well the types of language learning strategies employed by both types of personalities. The findings show that introvert learners tend to use meta-cognitive, cognitive, and affective strategy. To the contrary, extrovert learners tend to use social, memory, and compensation strategy. This learning strategy is identified and classified in line with Oxford's classification.
\end{abstract}

Keywords: language learning strategies, extrovert and introvert learners, speaking

\section{INTRODUCTION}

Every learning process needs to adopt a strategy or manner in order for the goal of learning to achieve. 'What' to use for learning and "how" to use it are the important things in the learning process. However, when people are learning a language, they are involved with many and different strategies. Some of these strategies give advantages, and some others are ineffective. When learning a foreign language, primary skills that should be mastered by English Foreign Language (EFL) Learner is speaking besides listening, writing and reading. Speaking is considered as a very difficult by students skill because it demands a lot of guts and preparation to speak correctly in a new language; therefore, when learning a new language or new words EFL learners tend to involve any strategies that can help them develop their speaking skill. Different strategies are available for language learners when learning in a foreign language. This strategy is referred to as a language learning strategy.

The term of Language learning strategies has been explained by many scholars in different ways. Brown [1] defined learning strategies modestly; he stated that learning strategies as a process that may contribute directly to learning. Some definitions of this term are chronologically listed in the table 1.

As discussed previously, to overcome obstacles that arise in learning speaking a foreign language, the speaker needs several strategies so that the language learning strategy becomes the main determinant. Because of the importance of language learning strategies, researchers are interested in knowing what types of language learning strategies are employed by English Department students in speaking activity and how they use them.

Regarding language learning strategy choice, several studies were conducted to determine what factors contribute to the choices of language learning strategies. They are language learning strategies used based on gender [8], [9]; age[10]; level of proficiency [11]; motivation [12]; religion [13] and also personality. Milne [14] investigates the correlation between personality traits and language learning strategies employed by learners enrolled in undergraduate foreign language courses at the University of Waterloo. 
Table 1. Learning Strategies' Definitions by various scholars

\begin{tabular}{lll}
\hline [2] & Bialystok & $\begin{array}{l}\text { Language learning strategies are an optional way of making use of available } \\
\text { information in improving a second language's competence. }\end{array}$ \\
\hline [3] & $\begin{array}{l}\text { Wenden } \\
\text { Robin }\end{array}$ & $\begin{array}{l}\text { Language learning strategy is strategy that contributes to language system } \\
\text { development which built by students and directly influence to learning. }\end{array}$ \\
\hline [4] & Chamot & $\begin{array}{l}\text { Learning strategies are approach, techniques, or intentional activities that } \\
\text { taken by students to help them in learning and remembering the information } \\
\text { and content of linguistic area }\end{array}$ \\
\hline [5] & $\begin{array}{l}\text { O'Malley \& } \\
\text { Chamot }\end{array}$ & $\begin{array}{l}\text { Learning strategies are specific behaviour or though that individuals employ } \\
\text { to understand, learn, or store every new informations }\end{array}$ \\
\hline [6] & Oxford & $\begin{array}{l}\text { Learning strategies are the behaviors that students take to make learning more } \\
\text { fun, more efficient, more independent, easier, faster and to new situation it } \\
\text { will more transferable }\end{array}$ \\
\hline [7] & Hall & $\begin{array}{l}\text { Learning strategies are behaviors employed by students to intervene their } \\
\text { learning }\end{array}$ \\
\hline
\end{tabular}

Al- Dail \& Freahat [15] analyze the types of students' personality and language learning strategy of Saudi EFL and found that extrovert employed compensation, cognitive strategies, and social strategies, and then Introvert used memory strategies, meta-cognitive and affective more likely. Marpaung \& Widyanotoro [16] investigate correlation among five personalities, language learning strategies and speaking skill of EFL learner and reveal that there is no correlation among them. On the other hand, Siska [17] analyze the speaking achievement between extrovert and introvert's students and they found Extrovert's students have better speaking achievement than Introvert's students. Different with the previous studies, this study examined the phenomena of language learning strategies based on personality: extrovert and introvert. It was investigating in case of EFL learners' speaking activity. This research investigated two strategies in general: Direct strategies consist of Memory, cognitive and compensation strategies, then Indirect strategies consist of Meta-cognitive, Affective and Social strategies as proposed by Oxford [6].

This research focused on how learners perform language learning strategies in speaking activity differed by their personality types because both students who are extrovert and students who are introvert have their own way to use the strategies in doing the learning. Table 2 shows the classification of language learning strategies by Oxford [6].

Table 2. Oxford (1990) language learning strategies

\begin{tabular}{ll}
\hline \multirow{3}{*}{ Direct Strategies } & 1) Memory strategies \\
\hline & 2) Cognitive strategies \\
\hline \multirow{3}{*}{ Indirect strategies } & 4) Meta-cognitive strategies \\
\hline & 5) Affective strategies \\
\hline & 6) Social strategies \\
\hline
\end{tabular}

\section{METHODS}

This research is a descriptive study with a qualitative approach to see natural things which occur to humans and some events or phenomena from the field directly. This research participants were thirty learners from one class of the third year undergraduate students from the English Education Department that consist of 8 males and 22 females. The participant is chosen by using purposive sampling because these participants have the criteria according to the study's objectives.

In answering the research questions, three instruments were used in this study. McCroskey introversion scale questionnaire by Richmond \& McCroskey [18] was used to determine the participants' personality types and expected that the level of conformity with the items can be determined by using a Likert scale of 1 to 5,. Questionnaire results were calculated to determine where participants took place, whether on the introversion or extroversion scale. The accumulation score's formula should be in the range 12-60. Therefore, 12 remains the lowest, labeled as extreme extroverts, and 60 remains the highest, labeled as extreme introverts. For more details, scores 12-24 representing highly extroverted; scores 25-35 labeled as moderate extroversion, 37-48 labeled as moderate introversion and 49-60 labeled as high introversion.

Meanwhile, at first, to obtain the lannguage learning strategies' information of EFL students in speaking activities in class, stimulated recall video was used to determine students' perceptions by providing video recordings of their learning strategies as a stimulus. According to Gass \& Mackey [19], stimulated recall has been promoted to seek 
unproven cognitive processes through simple observation. Zainil [20][21] found that this is as powerful change agent for making people aware of their language choice only after experiencing a memory stimulated interview. A stimulated memory interview was used in which the students watched a pre-selected video clip and gave the comments toward everything that was happening in class; what they were doing at the time and why [22]. SRI would be used to find out why students use certain learning strategies and the problems they may face. However, when this study was conducted, a corona outbreak changed every system of the teaching and learning process; all offline meetings moved to virtual meetings through zoom, cisco web-ex, e-learning, and other online platforms. Therefore, the researcher could not use the SRI efficiently because the speaking class often through the e-learning platform, so the Unstructured Interview privately is used instead. The list of the question was arranged based on the explanation of language learning types provided by Oxford [6].

\section{RESULT AND DISCUSSION 3.1 Personality types}

As stated before, this study aims to see what personality types of EFL learners are and to find out what the language learning strategies used employed by introvert as well extrovert students. So in the first step, a questionnaire was used to determine how many extrovert and introvert students was distributed by adapting McCroskey' introversion scale. The table below shows the result of a descriptive analysis of the introversion scale:

Table 3. Percentage of Introvert and Extrovert Learners

\begin{tabular}{ccc}
\hline Personality & Number of students & Percentage \\
\hline Introvert & 13 & $43,3 \%$ \\
\hline Extrovert & 17 & $56,7 \%$ \\
\hline Total & 30 & $100 \%$ \\
\hline
\end{tabular}

After statistically analyzed, the table above shows that most participants were extrovert, with $56,7 \%$ (17 students), and the rest were introverts $43,3 \%$ (13 students) of all participants.

\subsection{Language Learning Strategies}

To investigate the language learning strategies the learners employed in classroom speaking activity, the language learning strategy's taxonomy proposed by Oxford [6] was used for analyzing the data. The taxonomy contained two classifications of learning strategies in general; then they are divided into six classifications of strategies: (1) Direct strategies consist of Memory, cognitive and compensation strategies, (2) Indirect strategies consist of Meta-cognitive, Affective and Social strategies. The findings will be the extrovert and introvert group.

Table 4. Introvert's language learning strategies

\begin{tabular}{ccc}
\hline & Learning Strategies & Percentage \\
\hline 1. & Memory a Strategy & $13.1 \%$ \\
\hline 2. & Cognitive strategy & $20.3 \%$ \\
\hline 3. & Compensation strategy & $15.2 \%$ \\
\hline 4. & Meta-cognitive strategy & $30.5 \%$ \\
\hline 5. & Affective strategy & $17.2 \%$ \\
\hline 6 & Social strategy & $3.7 \%$ \\
\hline & Total & $100 \%$
\end{tabular}

The results in Table 4 show introvert students' language learning strategies in a speaking activity. According to the table, the most frequently used was the Meta-cognitive strategy $(30.5 \%)$, followed by cognitive strategy $(20.3 \%)$, and the least used learning strategies is the social strategy $(3.7 \%)$. The findings on the language learning strategies of EFL introvert learners are reported in Figure 1. 


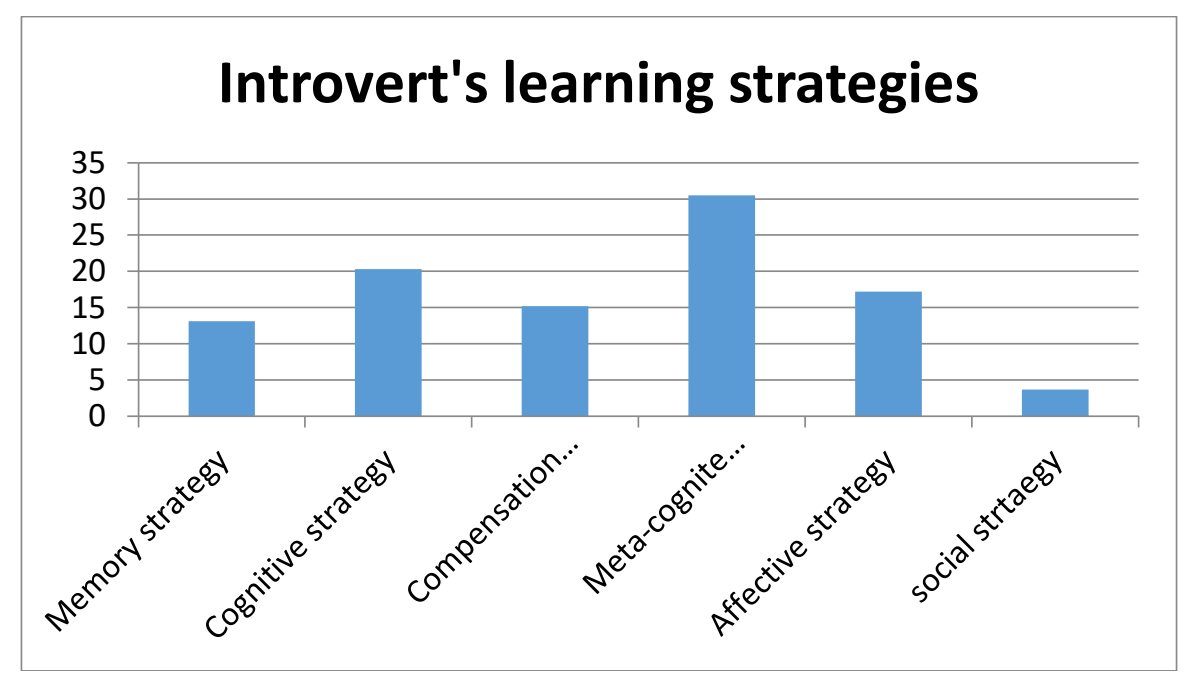

Figure 1. Introvert EFL learners' language learning strategies

Table 5. Extrovert's language learning strategies

\begin{tabular}{lcc}
\hline & Learning Strategies & Percentage \\
\hline 1. & Memory a Strategy & $21.6 \%$ \\
\hline 2. & Cognitive strategy & $13.1 \%$ \\
\hline 3. & Compensation strategy & $18.5 \%$ \\
\hline 4. & Meta-cognitive strategy & $4.2 \%$ \\
\hline 5. & Affective strategy & $10.7 \%$ \\
\hline 6. & Social strategy & $31.9 \%$ \\
\hline & Total & $100 \%$
\end{tabular}

The results in Table 5 show extrovert students' language learning strategies in a speaking activity. According to the table, the most strategy used was Social strategy (31.9\%), followed by memory strategy $(21.6 \%)$, and the least used learning strategies is the meta-cognitive strategy $(4.2 \%)$. The findings on the language learning strategies of EFL extrovert learners are reported in Figure 2.

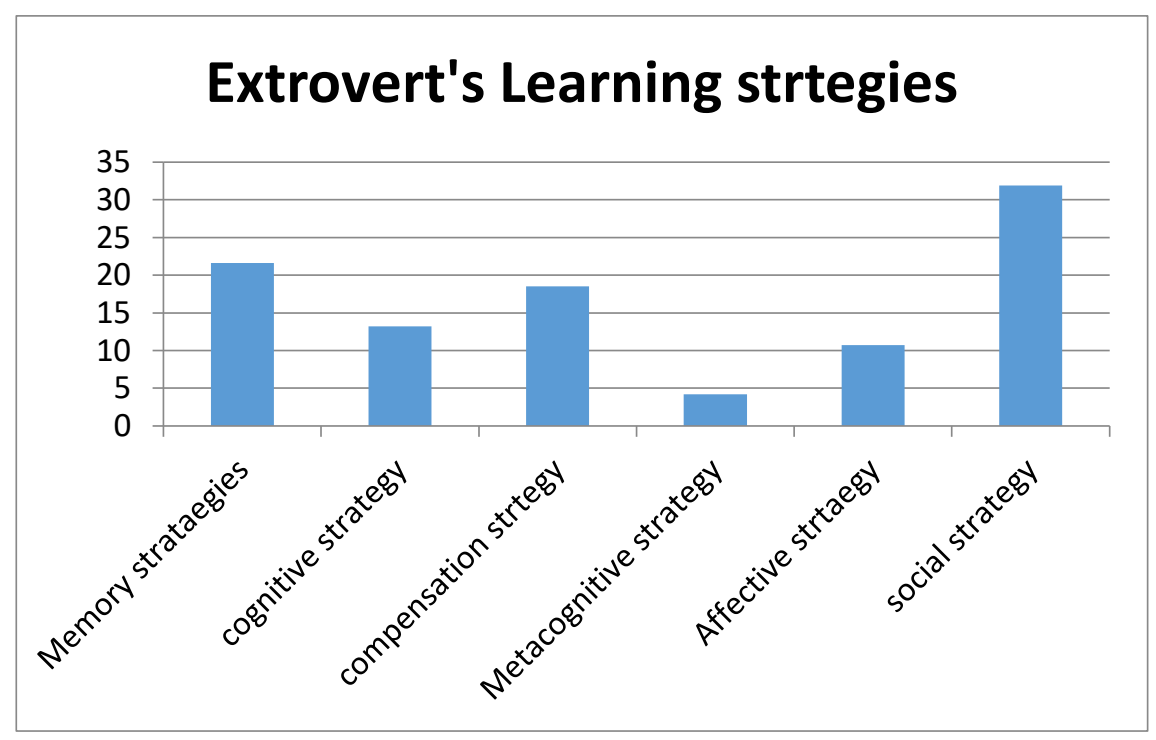

Figure 2. Extrovert EFL learners' language learning strategies 
Interestingly, the majority of the participant was categorized as an extrovert learner and it was also found that different personalities affect students' use of learning strategies from two aspects. First, in terms of frequency, introvert students' total number of learning strategies far exceeds the number of learning strategies used by introvert students. A possible explanation is that students with extrovert personalities tend to participate more than students with introvert personalities in a classroom activity. Introvert students expressed that they felt shy and anxious when practicing directly with their peers in the class. Therefore, they preferred to learn alone by using any strategies such as make an outline then practicing by themselves. Second, choose the type of learning strategy. In this study, six types of learning strategies used by introvert and extrovert students was found. However, there are different types of learning strategy choices by the two groups of students. The notable findings of this research are explained below.

\subsubsection{Meta-cognitive strategy}

The first notable findings in this research is the meta-cognitive strategy. This strategy is the most used strategy by introvert EFL learners. Three forms of meta-cognitive strategies; planning your learning, centering your learning, also evaluating your learning. Some examples of specific learning strategies of the introvert students related to setting goals/objectives and self-monitoring. sufficient speaking skills might be develop by those goals to survive in a environment of foreign language, and communicate with someone who speak the foreign language, negotiate foreign travel arrangements, and the like. And the other one is self-monitoring. In speaking, self monitoring is important, but correcting every speech difficulty should not be done by students because It would influence to their communication. Students should notice and their speech problem, without expecting to be perfect speaker, like those who are socially offensive or which cause confusion. Introvert learners prefer to use this strategy; they tend to correct themselves and repair themselves as well.

\subsubsection{Cognitive strategy}

Four forms of cognitive strategies are sending message, receiving, practicing and reasoning where most of the introvert participant chose as their learning strategy. One example of strategies that introvert learners used is practicing with sounds formally and formula patterns recognizing and using. When applying formally practicing with sounds, introvert learners tended to use the recording. In the classroom, they recorded their teacher's speaking or their lecturer; then, they would listen to the recording when they have been in their home. They imitated the way the teacher speak and compare the voice, style, and pronunciation. This finding is in line with Kustati [23], who states that the example of cognitive strategies can be practice by recording many sounds first, then practice by yourself in front of the mirror.

\subsubsection{Affective strategies}

Affective is the third frequency employed by the introvert learner and Three forms belong to affective strategies are lowering anxiety, encouraging self, and taking you the temperature of emotional. In speaking class, introvert learners said they tend to have high anxiety. To lower the anxiety, learners usually listen to music for around 10 minutes through their earphones; it helps them with anxiety when they start to speak or learn a new language. Sometimes, they are also making a positive statement such as 'I enjoy understanding a new language'.

\subsubsection{Social strategy}

Social strategy is the most frequent strategy that extrovert used in the speaking activity, such as cooperating with peers. EFL learners who are categorized as extrovert learners prefer learning to speak English by practicing with their friends. For example, they make any role play then speak in English, and sometimes they also ask the correction from their peer about their speaking, like how about their pronunciation, grammar, fluency or anything, so it is no wonder become the most frequent strategy employed by extrovert learners.

\subsubsection{Memory strategy}

Two key functions of memory strategy are Storage and retrieval of every new information. These strategies facilitate learners store the important thing they heard in memory and read in the new language base. One example of memory strategy is ' using the keywords'. This strategy combines sounds and images so that learners can more easily remember what they heard or read in the new language. According to an interview, some learners said that they use this strategy in two ways: first, identify familiar words, generate a visual image of the new word, and interact somehow. This strategy helps them easier to speak English.

\subsubsection{Compensation strategy}

The last strategy used by learners in speaking activity is the compensation strategy. This strategy helps learners to overcome knowledge limitation. From the interview, most of the extrovert learner said that this compensation talk as they favorite strategy because when they lost word or have limitation about the topic they want to say, they will use gesture or mime during the conversation to indicate the meaning. And also the other example of this strategy is using a synonym. For example: when a learner could not say a towel in English, she says 'a thing that can dry out your body or hair' at the time.

\section{CONCLUSION}

The findings of the this study lead to the implication for higher education in foreign language teaching. The advantages of applying different learning strategies is to overcome the learning barriers in different situations. They can be included as part of the teaching agenda. The way in choosing more appropriate learning strategies and use them creatively and efficiently is a useful skill that these students can acquire. The complex concept of learning strategies in 
this research is necessity to be understood well in order to improve language learning development program.

\section{REFERENCES}

[1] Brown, H, D. (1980). Principle and practices of language learning and teaching. Englewood Cliff, NJ: Practice Hall.

[2] Bialystok, E. (1978). A theoretical model of second language learning. Journal of research in language studies, 28 (1), 69-83.

[3] Wenden, A., \& Rubin, J. (1987). Learner strategies in language learning. Hertfordshire: Prentice Hall.

[4] Chamot, A.U. (1987) The Learning Strategies of ESL Students. In: Wendenm A. and Rubin, J., Eds., Learner Strategies for Second Language Acquisition, Prentice Hall, Englewood Cliffs, 71-83.

[5] O’Malley, J. M., \& Chamot, A.U. (1990). Learning strategies in second language acquisition. Cambridge: Cambridge University Press.

[6] Oxford, R. L. (1990). Language learning strategies: What every teacher should know. New York: Newbury House Publishers.

[7] Hall, J. K. (2001). Methods for teaching foreign languages. Upper Saddle River, NJ: Prentice Hall.

[8] Alhaysony, M. (2017). Language Learning strategies use by Saudi EFL students: The effect of duration of English language study and gender. Theory and Practice in Language Studies, 7(1), 18.

[9] Mahmud, M. \& Nur, S. (2018). Exploring students' learning strategies and gender differences in English language teaching. International Journal of Language Education, 2(1), 51-64.

[10] Chen, M.L. (2014). Age Differences in the Use of Language Learning Strategies. English Language

TeachingJournal, 7 (2),144-151.

[11] Yustitiasari, H., Junining, E., \& Sahiruddin. (2020). The Relationship between Language Learning Strategies used by Vocational Students and Level of Proficiency,. E journal of Linguistic, 14 (1), 128-136.

[12] Ranjan, R., \& Philominraj, A. (2020). Language Learning Strategies, Motivation and Gender in Foreign
Language Context. Universal Journal of Educational Research, 8(2), 591-604.

[13] M, Laeha. (2015). English learning strategies based on personality traits: a comparison of moeslim and non-moeslim. Master of Art of Teaching English as an International Language : Songkla University.

[14] Milne, E.W. (2020). Personality types and Language learning strategies used by university students. Master of Art of Intercultural German Studies: Waterloo University.

[15] Al-Dakhail, H. K.,\& Freahat, M. N.(2019). Saudi EFL Students' Personality Types and Their Language Learning Strategies. Journal for study of English Linguistics, 7 (1), 55-76

[16] Marpaung, V. D., \& Widyantoro, A. (2020). EFL Learners' Big Five Personalities, Language Learning Strategies, and Speaking Skills. Indonesian Journal of EFL and Linguistics, 5(1),73-96.

[17] Siska, W. (2015). An analysis of extrovert and Introvert students in their speaking achievement (A study at the first year students of English Department of STKIP PGRI West Sumatera). English Department: STKIP PGRI West Sumatera.

[18] Richmond, V. P., \& McCroskey, J. C. (1998). Communication apprehension, avoidance and effectiveness b (5th Ed.). Boston: Allyn \& Bacon.

[19] Gass, S. M., \& Mackey, A. (2000). Stimulated Recall Methodology in Second Language Research. Mahwah, New Jersey: Lawrence Erlbaum associates, Publishers

[20] Zainil, Y. (2017). Stimulated Recall : Unpacking Pedagogical Practices of Code-switching in Indonesia (Published Dissertation). Melbourne: Deakin University Australia

[21] Zainil, Y. (2019). Pedagogical Practices of Code Switching in EFL Classrooms in Padang, Indonesia. Social Sciences on Sustainable Development for World Challenge: The First Economics, Law, Education and Humanities International Conference, KnE Social Sciences, pp. 634-643.

[22] Zong, Q. (2010). The Effect of Chinese ESL Learners' Beliefs on their Autonomous Learning. Studies in Self Access Learning Journal, 1 (3), 212 - 222.

[23] Kustati, M. (2007). Language Learning strategies. Padang : Hayfa press 